\title{
皮膚リンパ腫に対する放射線治療の役割
}

\author{
大塚 幹夫 \\ 福島県立医科大学医学部皮膚科学講座
}

要旨 皮膚悪性リンパ腫の治療における放射線療法の位置付けを文献的に検討した。ほとん どの報告は症例比較研究などの非実験的記述であり，各治療法間の患者背景因子を一致させ ておらず，エビデンスの質が高いとは言えないものであった。菌状息肉症では全身の体表照 射が予後を改善するかという点が争点の一つになっているが，明確な見解は出ていない。NK 細胞リンパ腫については皮膚原発例のまとまった報告がなく，鼻腔原発例の結果から考える と, 放射線療法と通常量の化学療法の併用は放射線療法単独の効果を上回らない可能性が示 されている。皮膚 B細胞リンパ腫では放射線療法は有効であり，第 1 選択の治療法の一つと考 えられるが，一部にみられる予後不良例で放射線療法のみでは不十分な可能性がある。また， 皮膚 B 細胞リンパ腫はEORTC 分類と REAL/WHO分類の違いが大きく, 複数の報告間の比較 が困難である。

\section{Radiation therapy in the management of primary cutaneous lymphoma}

\section{Mikio OHTSUKA}

Department of Dermatology, Fukushima Medical University School of Medicine

In this report, a role of radiation therapy in the management of primary cutaneous lymphoma was reviewed. There is no randomized trial to evaluate the efficacy of treatment modalities for primary cutaneous lymphoma except one, which compares combination radiation and chemotherapy with topical therapy in the initial treatment of mycosis fungoides. Most of the articles referring to treatment outcomes were descriptive studies. Well-designed controlled studies may be required to establish the significance of radiation therapy for cutaneous lymphoma. [Skin Cancer (Japan) 2004 ; 19: 72-79]

Key words : Primary cutaneous lymphoma, Radiation therapy, Mycosis fungoides, Primary cutaneous B-cell lymphoma

放射線療法は化学療法と交叉耐性を示すこと なく，多くのリンパ腫細胞に有効性を示すため リンパ腫の治療においては非常に有効な手段で ある。皮膚原発のリンパ腫に対しても放射線療 法は以前から用いられてきたが，その有効性に
関して化学療法等の他の治療法と厳密に比較し た研究は現在までほとんど行われていない。本 稿では，皮膚原発リンパ腫の放射線療法の適応 に関する文献的考察を行う。 


\section{1. 菌状息肉症 (MF)}

2002年に刊行された皮膚悪性腫瘍取り扱い規 約では局所療法としては Stage II b から StageIV の病変部への電子線照射, 全身療法としては Stage I から Stage III で全身の体表照射（total skin surface electron beam therapy; TSEBT) が治療の選択肢としてあげられている。

\section{1）局所放射線療法}

局所放射線療法は患者のQOL改善のための 対症療法であり，ステロイド外用剤やPUVA療 法など日常外来で手軽に行える局所療法で効果 がそしい局面期および腫瘍期病変に対して局所 電子線照射が選択されることが多いのではない かと推察される。PUVA療法やステロイド，抗 腫瘍剂外用療法など他の局所療法との効果を比 較した論文はみられない。Cotter ら ${ }^{11}$ は110カ 所の病変（約半数が腫瘍期病変）に局所電子線 療法を行い，20Gy 以上では全例 CR となり，照 射野での再発は20-30Gyでは21\%にみられ， 30Gy 以上では照射野内の再発は2られていな いと報告している。Wilsonら ${ }^{2)}$ の報告では T1 期病変に対して20Gyの照射を行い, 完全寞解 率 $97 \% ， 5$ 年および10 年後の disease free sur- vival はそれぞれ 75\%および64\%と良好な結果 を報告している。

\section{2) TSEBT}

全身療法であるTSEBTは病変部のコントロ ールとともに，病期の進展を抑え，長期予後を 改善可能か否かが効果判定のポイントであると 考えられる。1970年代から MFに対する TSEBTの治療成績が数多く報告されてきたが, 他の治療法との無作為化比較試験が行われたの は 1 報のみである3!。その報告では，103名の MF患者を対象として30GyのTSEBT および化 学療法 (cyclophosphamide, doxorubicin, etoposide, vincristine）の併用群を mechlorethamine 外用療法 (ME療法：0.02\%W/V) の群と比較 している。その結果，完全寛解率㧍よび部分寛 解以上の奏効率は併用群が ME療法より有意に 優れていたが，overall survival（OS）および disease-free survival (DFS) では両群間に有 意差はみられないという結果であった（表1）。 この報告では化学療法を併用しているため TSEBT 単独と外用療法単独の比較はできない が，著者らは aggressive therapyは外用療法と 比較してMFの予後を改善しないと結論づけて いる。しかし，この報告はすべての stageの患 者を対象としているため, stage II B以上の進

表 1．菌状息肉症に対する放射線療法を含む治療法の無作為化比較試験

\begin{tabular}{|c|c|c|c|c|c|}
\hline Therapy & No. of Pts & $\mathrm{CR}(\%)$ & $\mathrm{PR}(\%)$ & $N C(\%)$ & $\mathrm{PD}(\%)$ \\
\hline $\mathrm{RT}+\mathrm{CT}$ & 52 & 38 & 52 & 4 & 2 \\
\hline \multirow[t]{2}{*}{ Mechlo. } & 51 & 17 & 47 & 22 & 12 \\
\hline & \multicolumn{2}{|c|}{$\mathrm{RT}+\mathrm{CT}$} & Mechlo. & \multicolumn{2}{|r|}{$p$ value } \\
\hline CR & \multicolumn{2}{|c|}{$38 \%$} & $17 \%$ & \multicolumn{2}{|r|}{0.032} \\
\hline \multicolumn{2}{|l|}{ Response rate } & $90 \%$ & $64 \%$ & \multicolumn{2}{|r|}{0.003} \\
\hline \multicolumn{2}{|l|}{ DFS(median) } & $12.9 \mathrm{mo}$ & $21.3 \mathrm{mo}$ & \multicolumn{2}{|r|}{0.19} \\
\hline \multicolumn{2}{|l|}{ OS(median) } & $91 \mathrm{mo}$ & $>76 \mathrm{mo}$ & \multicolumn{2}{|r|}{ n.s. } \\
\hline
\end{tabular}

CT: chemotherapy, Mechlo: mechlorethamine, PR: partial remission, NC: no change, PD: progressive disease 
行期の患者の割合が65\%以上であり，病初期 の患者にTSEBTを行った場合の長期予後につ いては類推できない ${ }^{4)}$ 。

無作為化比較試験ではないが，病期別の TSEBT 単独療法とME療法の比較がいくつか 報告されている。Hamminga ら ${ }^{5)}$ はリンパ節お よび内臓病変のない患者に対するTSEBT 単独 療法（28～35Gy）と ME療法 $(0.025 \% \mathrm{~W} / \mathrm{V}$, 連日全身塗布）の比較を行っている。腫瘤を有 しない患者に対してはTSEBT療法では15例全 例 CRであるが，ME療法では 17 例中 14 例が CRであり， 3 例はPRであった。 TSEBTでCR となった 15例のうち 8 例は再発しており，CR の維持期間の中央值は掞よそ10カ月であった。 $\mathrm{ME}$ 療法で $\mathrm{CR}$ となった 14 例は維持療法を継続 し， 3 年以上の観察中央期間で再発はみられて いない。腫瘤病変を有する症例ではTSEBT 療 法では 6 例中 3 例が $\mathrm{CR}$ となり，ME療法では 4 例中 CRは 1 例のみである。TSEBT 療法群 はCR後の維持療法を行っていないのに対し， $\mathrm{ME}$ 療法群では週 1 回塗布の維持療法を行った ことや，病期および性別などを両群間で一致さ せていないため，この報告では両群でのCR維 持期間を直接比較することはできない。

$\mathrm{Kim} ら^{6 ）}{ }^{7)}$ は $\mathrm{T} 1$ 期および $\mathrm{T} 2$ 期の MF 患者の 長期予後に関する検討のなかでTSEBT療法と $\mathrm{ME}$ 療法の効果を比較している（表2）。T1の 患者に対しては34名にTSEBT療法，73名に $\mathrm{ME}$ 療法が行なわれており，CR率，5年後およ び10年後の FFR（freedom from relapse）では TSEBT療法が有意に優れていたが，10年後の
OSおよび disease-specific survival（DSS）で はME療法と有意差がみられなかった。また， $\mathrm{T} 1$ 期の長期生存率は人種, 年齢, 性別をマッ チさせた対照群と差がなかったと報じている。 T2期ではTSEBT 療法は 106名, ME療法は63 名に行われており，CR率はTSEBT療法が優 れているが，10年後のFFR，OS，DFSでは両 群で差が認められていない。

Chinn ら ${ }^{8)}$ は T2 およびT3期の MF患者に TSEBT (36Gy，腫瘤部には10～15Gyの追加 照射）および $\mathrm{ME}$ 療法（0.01〜0.02\%W/V，腫 瘤部には電子線の併用。CR後は $0.01 \% て ゙$ 維持 療法）の比較を行った。T2期に対して CR 率 はTSEBT療法が76\%，ME療法が39\% と Kim の報告とほほ同様の結果であり, TSEBTの方 が有意に優れている $(\mathrm{p}=0.03)$ 。FFRを TSEBT療法のみ, TSEBTでCR後にMEによ る維持療法, ME療法で比較すると, TSEBT 療法のみと ME療法では有意差はなく, TSEBT 療法後にMEによる維持療法を行った 群が有意にFFR率が高い結果となった。 5 年, 10 年後の OSではいずれの群にも有意な差はな かった。T3ではCR率はTSEBT療法がME療 法より有意に優れているが (44\% vs 8\%,p< 0.05)，OSでは有意差はない。

以上の結果では, T 1 T 3 のいずれの病期 でも TSEBTはME療法よりも CR 率が有意に 高く，皮膚症状のコントロールという点では TSEBTはME療法より優れているが，長期の OSでは有意の差がみられない。ただし T 1 期 およびT 2 期でTSEBT後にMEによる維持療

表 2. $\mathrm{T} 1$ 期および $\mathrm{T} 2$ 期菌状息肉症の長期予後

\begin{tabular}{ccccccc}
\hline Stage & Treat. & No. & CR(\%) & DFS(\%:10y) & OS(\%:10y) & DSS(\%:10y) \\
\hline T1 & TSEBT & 34 & 97 & 58.7 & 87 & 100 \\
& Mechlo & 73 & 68 & 45 & 87 & 95 \\
& & & & & & \\
T2 & TSEBT & 106 & 62 & 17.1 & 54 & 80 \\
& Mechlo & 63 & 49 & 26.9 & 50 & 81 \\
\hline
\end{tabular}


法を施行した場合にはFFRがME療法よりも 優れている。一方, Jonesらは無作為化比較試 験ではないが, 最適な条件のTSEBT $(4 \mathrm{MeV}$ 以上で 35〜36Gy）で行うことにより Stage IA の患者ではOSの延長につながる可能性を指摘 している4)9!。

\section{NK細胞リンパ腫}

NK細胞リンパ腫は鼻腔に原発することが多 く, 皮膚原発よりも高頻度である。皮膚原発 例も多く報告されているが，そのほとんどは 症例報告, 症例報告のまとめであり治療効果 の比較を行った報告はみられない。鼻腔原発 例では無作為化比較試験ではないが, 化学療 法と放射線療法の効果比較が可能な報告がい

\section{くつかみられる。}

Cheung ら ${ }^{10)}$ は限局期の nasal NK/T-cell lymphomaの患者79名に対し, 放射線療法

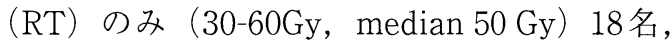
化学療法 (CHOP, ProMACE-CytaBOM, $\mathrm{CEOP}$ 等）および放射線療法の併用（combined modality therapy；CMT）を61名に行っ た。RT群では患者の年齢, 治療開始時の international prognostic index (IPI) がCMT群より も有意に高かったが, stageや performance status (PS), LDH值などに相異はみられなか った。RT群とCMT群でCR率，5年DFS，5年 OSはそれぞれ 78\% vs 66\%,31\% vs 36\%,30\% vs 40\%でありいずれも有意差はみられなかった。

$\operatorname{Kim} ら^{11)}$ も 143 人の限局期患者を対象に同様 の比較を行った。その結果, RT群 (40-54Gy, median 50Gy) と CMT (CHOP，BACOPまた は $\mathrm{m}-\mathrm{BACOP}+\mathrm{RT})$ 群で $\mathrm{CR}$ 率， 5 年 DFS, 5 年 OS はそれぞれ $69 \%$ vs $67 \%, 38 \%$ vs 35\%, $32 \%$ vs 27\%でありいずれも有意差はみられて いない。CMTで化学療法を先行させた群では 化学療法のみでは CR率は $5 \%$ であり, その他 の患者はRTを追加することにより CRになっ ている。
これらの結果から，RTのみでも約 70\%の患 者はCRとなるがその多くが再発している。再 発部位は約半数が照射野内であり，その残りは 照射野内および照射野外での再発であり，放射 線療法のみでは局所再発を充分に抑えることが できていない。しかし，RTと化学療法を併用 してもOS, DFSの改善はみられていない。ま た, 無治療群との比較はなくRTあるいはRT と化学療法の併用が無治療と比べて生存期間を 延長するか否かは不明である。

\section{3. 皮膚原発 CD30陽性未分化大細胞型 リンパ腫 (PCALCL)}

皮膚のCD30 陽性大細胞型リンパ腫に関し て，もっとも多くの症例で予後を検討している のはBekkenkの報告である ${ }^{12)} 。$ 彼らは， EORTC 分類に従い, CD30 + anaplastic large cell lymphoma と non-anaplastic large cell lymphomaを同一の疾患単位として primary cutaneous CD30 + large cell lymphomaとしてまと め, 79例の予後を検討している。初期治療と しては38例 (48\%) がRT，15例（19\%）が外 科的切除, 6例 (8\%) に化学療法を行い, 15 例は自然退縮したため治療を行っていない。治 療法別の CR率や経過には言及していないが， 77 例 (99\%) がCRになり，5年，10年後の disease-related survival はそれぞれ96\%であ り，かなり良好な経過を示す。

Beljaards ら ${ }^{13)}$ は primary cutaneous CD30+ large cell lymphoma 47例のまとめの報告を行 っている。初期治療としては放射線療法 (9例), 外科的切除 (23例), 切除後の放射線療法 (4 例), 化学療法（7例）などが行われており， いずれも100\% CRになっている。観察期間は いずれのグループでも約 50 カ月であり，その 間の再発はRT群および外科切除単独群で約 50\%であり, RTと切除の併用群および化学療 法群では約 $80 \%$ である。疾患関連死は 4 例 （8\%）のみであった。以上の結果から PCALCL 
はRTや切除のみでも経過は良好であり，これ らが治療の第 1 選択になると思われる。

\section{4. 皮膚原発 $B$ 細胞リンパ腫}

多数例の皮膚原発 B 細胞リンパ腫 $(\mathrm{PCBCL})$ に対しRTの効果を検討した報告がいくつかみ られるが，それらの報告は無作為化比較試験で はなく，使用されている分類も様々であるとい う問題点がある。

Santucci ら ${ }^{14)}$ は83例の PCBCLの臨床, 病理 所見を検討した。そのうち follow-up データが 判明しているのは65例であり, RTが44例，化 学療法が6例, 外科的切除が7例に行われてい る。これらの患者はいずれもCRとなり，再発 率およびDFSの中央值はそれぞれ RTが $32 \%$, 20 力月, 化学療法が $50 \%, 12$ 力月および切除 が14\%， 7 カ月である。全体では観察期間の中 央值 26 カ月で疾患関連死は RTを行なった 1 例 のみである。治療法別の患者背景は一致させて いないが，これらの結果からはRTの方が化学 療法より優れた結果と言えそうである。

Kirova ら ${ }^{15)}$ は25例の PCBCLにRTを行って いる。CR率は $92 \% ， 1$ 年後の DFSは $92 \% ， 5$ 年 後の DFS は75\%である。再発は多くみられる が，すべて照射野外であったと報告している。 疾患関連死は 2 例にみられている。Piccino ら ${ }^{16)}$ も31例の PCBCLにRTを行い，全例CRとなっ ている。そのうち21例 (68\%) が再発してお り，そのほとんどが照射野外の皮膚またはリン パ節であった。これらの再発病変はRTの追加 や化学療法で全例再びCR となっている。以上 3 つの報告はいずれも PCBCLの詳細な病型分 類には触れず，いろいろな病型を包含している と推測される。

PCBCLの病型別にみたRTの効果に関しても 幾つかの報告が出されている。Mirzaら ${ }^{17)}$ cutaneous follicular lymphoma 32 例のまとめを 報告している。治療法ではRT 単独が18例, 化 学療法単独 2 例, RT と化学療法併用 4 例, 外科
切除 5 例, 外科切除と RT併用 2 例, 外科切除 と化学療法併用 1 例であり, 全体で 5 年の DFS は65\%であり治療法による有意な差はみられ なかった。また，観察期間の中央值は36力月 で疾患関連死は1例もみられていない。Franco $ら^{18)} も$ 同様に18例の cutaneous follicular lymphomaのまとめを報告しており，RT単独が4 例, 外科切除が 10 例, RT と切除併用が 4 例と なっている。全例CRであり，そのうち8例が 再発し, 再発までの平均期間は 47.3 カ月であっ た。平均観察期間は 43.7 月であり, 疾患関連 死は1例もない。再発はRTおよび切除が約半 数ずつであり,併用群には再発がみられないが, 併用群の平均観察期間が 32 力月と比較的短い ことが要因として考えられる。上記 $2 つ の$ 報告 はREAL/WHOに準じた診断によるものであ り, 濾胞形成性増殖のパターンを示し, 免疫染 色や bcl-2発現の点でも節性 follicular lymphoma と類似の特徵を有する。

Cerroni ら ${ }^{19)}$ は 15 例の primary cutaneous follicle center cell lymphomaの症例をまとめてお $\eta, \mathrm{RT}$ 単独が 7 例, 外科切除が 5 例, RT $\mathrm{R}$ と切 除併用が 3 例となっている。平均観察期間は 48.7 月であり, 疾患関連死は 1 例もない。 Rijlaarsdam ら ${ }^{20)}$ はEORTCが提唱される前年 に follicular center cell origine $の$ cutaneous Bcell lymphoma 55例の治療法と予後を検討し た。40例にはRTを行い，そのなかに下肢原発 例（EORTC分類で diffuse large B-cell lymphoma of the legに相当すると思われる）が 6 例含まれている。一方，15例には化学療法 （主にCHOPまたはCOP）を行い，下肢原発は 2 例である。下肢原発で化学療法を行った 1 例 を除くすべての症例がRT, 化学療法とも CR になっている。再発はRTでは 8 例あり，その うち 4 例が下肢原発例であった。下肢原発例の RTでの再発率は $80 \%$ であり, 下肢原発以外で はRTでの再発率は $12 \%$ である 2 年および 5 年の予測生存率は $92 \%$ および $89 \%$ であり，下 肢原発例を除いた場合それぞれ100\%および 
96\%と非常に予後良好である。また, 疾患関連 死が 3 例であり，いずれも下肢原発の症例であ った。化学療法群では再発は 5 例 (33\%) であ り，疾患関連死は体幹に生じた 1 例のみであっ た。

Sarris ら ${ }^{21)}$ はREAL分類に準じて分類した 19 例の diffuse large B-cell lymphomaに対して, 14 例に化学療法単独 (CT) または化学療法と $\mathrm{RT}$ の併用 (CMT)，4例はRT単独の治療 (30 〜 50Gy, median 40Gy）を行っている（表 3）。 12 年の DFS およびOSをCTまたはCMTとRT とで比較すると，DFSは 71\% vs 0\%, OSは77\% vs 25\%であった（表3）。患者背景の詳細につ いては述べられていないが，CTまたはCMTの ほうがRTよりも有意に予後が良い。

Bekkenkら ${ }^{22)}$ はEORTC分類に従って, 多発 病変を有する primary cutaneous follicle center cell lymphoma (PCFCCL) および primary cutaneous diffuse large B-cell lymphoma of the leg (PCLBCL) の治療指針の検討を行ってい る(表 3)。16 例の PCFCCL おょび 5 例の PCLBCLに対しRTおよびCTを行い，その予 後を比較している。その結果 PCFCCLではRT およびCTで CR率，再発率ともに大きな差は
なく，PCLBCLはRTは 1 例のみであるがCR 後に再発している。化学療法施行群（主に COP）はCRは 4 例中 1 例のみであり, その 1 例も再発している。

以上の報告から， PCBCL全体でみるとRTの 反応は良好であり，CR率が非常に高い。照射 野外の再発が稀ならずみられるが, 再発病変に 対してRTは有効であり，再発がみられた例で も生命予後は良好である。病型別にみた場合, REAL/WHO 分類で follicular lymphomaに分類 されるものはRT, 切除, 化学療法いずれでも CR率は高く, 長期経過でも疾患関連死はなく, 予後良好である。EORTC分類の PCFCCLは cutaneous follicular lymphoma と同様に RTに 対する反応性, 予後ともに非常に良好である。 化学療法に伴う身体的な負担を考えると, これ らに対しては現時点ではRTが第 1 選択の一つ と考えられる。しかし, REAL/WHO分類の diffuse large B-cell lymphomaに分類される症 例については生命予後不良例が他の病型より多 く，またEORTC分類での下肢に生じた PCLBCLはRTに対する反応性が劣り, 予後も 不良例がみられることから RT以外の治療を第 1 選択とすべきであると考えられる。

表 3. 皮膚原発follicle center cell lymphoma およびdiffuse large B-cell lymphomaの治療成績

\begin{tabular}{cccccc}
\hline Author & Diagnosis & Therapy & No. of Pts & CR(\%) & No. of Relapse \\
\hline Bekkenk & PCFCCL & RT & 5 & $5(100 \%)$ & $0(0 \%)$ \\
(JCO 1999) & & CT & 9 & $9(100 \%)$ & $3(33 \%)$ \\
& & others & 2 & $1(50 \%)$ & $1(100 \%)$ \\
\cline { 2 - 6 } & PCLBCL & RT & 1 & 1 & 1 \\
& & CT & 4 & $1(25 \%)$ & 1 \\
\hline
\end{tabular}

\begin{tabular}{cccccc}
\hline Author & Diagnosis & Therapy & No. of Pts & DFS(12y) & OS(12y) \\
\hline Sarris & PCDLCL & RT & 10 & 0 & 25 \\
(JCO 2001) & & CT & 33 & 71 & 77 \\
\hline
\end{tabular}

PCFCCL: primary cutaneous follicle center cell lymphoma PCLBCL: primary cutaneous large B-cell lymphoma of the leg PCDLCL: primary cutaneous diffuse large B-cell lymphoma 


\section{5. 成人 $T$ 細胞白血病/リンパ腫}

成人 $\mathrm{T}$ 細胞白血病/リンパ腫（ATLL）のく すぶり型の皮膚病変は皮膚腫瘤型と紅斑・丘疹 型に分類される。腫瘤型はリンパ腫型と同等に 予後不良であり，RTはpalliative care としての 役割である。紅斑丘疹型に対しては現在ではス テロイド外用や紫外線療法による皮膚病変のコ ントロールが主体であるが，RTにより皮膚病 変をコントロールすることが生命予後を改善す るかどうかを検討した報告はみられない。 ATLLの皮膚病変に対してRTを施行した報告 は $\mathrm{Baba}{ }^{23)}$ の16例の報告があるが，皮膚病変 の詳細が記載されていないため, 腫瘤性病変か 紅斑・丘疹かは不明である。彼らは化学療法が 奏効しなかった皮虚病変を有するくすぶり型 ATLL13例中 8 例にTSEBT，5例に局所照射 を行いそのうち 12 例がCRとなっている（いず れも 30Gy)。しかし，6例が再発し（8～26力 月, 中央值 4 力月), 5 例が疾患関連死してい る ( $7 \sim 147$ 力月, 中央值 36 力月)。一方, 皮 膚病変の再発がない 6 例は 3 例がATLL以外の 死亡 (11 46 カ月)，2 例が疾患関連死（9 カ 月および 12 カ）である。再発例の多くは照射 野および照射野外の両方に再発病変を生じてい る。従って, 皮䖉病変のみのくすぶり型 ATLL に対してRTは短期的には局所のコントロール が可能であるが，30Gyでは局所再発が抑えられ ない。

\section{6. まとめ}

これまで述べてきたように皮膚リンパ腫の放 射線療法に関して, 無作為化比較試験は 1 報し かなく，ほとんどは各治療法間の患者の年齢, 性別, 病期などの背景因子を一致させていない, 症例比較研究などの非実験的記述であり, エビ デンスの質が高いとは言えないものであった。 また，皮膚リンパ腫に関する統一的な分類が確
立されていないため，特にB細胞リンパ腫では 診断にばらつきがあり幾つかの報告を合わせた メタアナリシスが困難である。今後は診断の統 一とそれに従った比較試験の施行が望まれる。

\section{文献}

1) Cotter GW, Baglan RJ, Wasserman TH, et al: Palliative radiation treatment of cutaneous mycosis fungoidesa dose response. Int J Radiat Oncol Biol Phys, 9 : 1477-1480, 1983

2 ) Wilson LD, Kacinski BM, Jones GW : Local superficial radiotherapy in the management of minimal stage IA cutaneous T-cell lymphoma (Mycosis Fungoides). Int J Radiat Oncol Biol Phys, 40: 109-115, 1998

3 ) Kaye FJ, Bunn PA Jr, Steinberg SM, et al : A randomized trial comparing combination electronbeam radiation and chemotherapy with topical therapy in the initial treatment of mycosis fungoides. N Engl J Med, 321 : 1784-1790, 1989

4) Jones GW, Wilson LD : Mycosis fungoides and total skin electron beam radiation. Blood, $89:$ 3062-3064, 1997

5) Hamminga B, Noordijk EM, van Vloten WA : Treatment of mycosis fungoides : total-skin electron-beam irradiation vs topical mechlorethamine therapy. Arch Dermatol, $118: 150-153$, 1982

6 ) Kim YH, Jensen RA, Watanabe GL, et al : Clinical stage IA (limited patch and plaque) mycosis fungoides. A long-term outcome analysis. Arch Dermatol, 132 : 1309-1313, 1996

7) Kim YH, Chow S, Varghese A, et al : Clinical characteristics and long-term outcome of patients with generalized patch and/or plaque (T2) mycosis fungoides. Arch Dermatol, 135 : 26-32, 1999

8) Chinn DM, Chow S, Kim YH, et al : Total skin electron beam therapy with or without adjuvant topical nitrogen mustard or nitrogen mustard alone as initial treatment of T2 and T3 mycosis fungoides. Int J Radiat Oncol Biol Phys, 43 : 951-958, 1999

9) Jones GW, Tadros A, Hodson DI, et al : Prognosis with newly diagnosed mycosis fungoides after total skin electron radiation of 30 or 35 GY. Int J Radiat Oncol Biol Phys, 28 : 839-845, 1994

10) Cheung MM, Chan JK, Lau WH, et al : Early stage nasal NK/T-cell lymphoma : clinical outcome, prognostic factors, and the effect of treatment 
modality. Int J Radiat Oncol Biol Phys, 54 : 182-190, 2002

11) Kim GE, Lee SW, Chang SK, et al : Combined chemotherapy and radiation versus radiation alone in the management of localized angiocentric lymphoma of the head and neck. Radiother Oncol, 61:261-269, 2001

12) Bekkenk MW, Geelen FA, van Voorst Vader PC, et al : Primary and secondary cutaneous CD30(+) lymphoproliferative disorders : a report from the Dutch Cutaneous Lymphoma Group on the longterm follow-up data of 219 patients and guidelines for diagnosis and treatment. Blood, $95: 3653-3661$, 2000

13) Beljaards RC, Kaudewitz P, Berti E, et al : Primary cutaneous CD30-positive large cell lymphoma: definition of a new type of cutaneous lymphoma with a favorable prognosis. A European Multicenter Study of 47 patients. Cancer, 71 : 2097-2104, 1993

14) Santucci M, Pimpinelli N, Arganini L : Primary cutaneous B-cell lymphoma : a unique type of lowgrade lymphoma. Clinicopathologic and immunologic study of 83 cases. Cancer, 67 : 2311-2326, 1991

15) Kirova YM, Piedbois Y, Le Bourgeois JP : Radiotherapy in the management of cutaneous Bcell lymphoma. Our experience in 25 cases. Radiother Oncol, 52:15-18, 1999

16) Piccinno $R$, Caccialanza $M$, Berti E, et al : Radiotherapy of cutaneous B cell lymphomas : our experience in 31 cases. Int J Radiat Oncol Biol
Phys, 27:385-389, 1993

17) Mirza I, Macpherson N, Paproski S, et al : Primary cutaneous follicular lymphoma : an assessment of clinical, histopathologic, immunophenotypic, and molecular features. J Clin Oncol, 20 : 647-655, 2002

18) Franco R, Fernandez-Vazquez A, Rodriguez-Peralto JL, et al : Cutaneous follicular B-cell lymphoma : description of a series of 18 cases. Am J Surg Pathol, 25 : 875-883, 2001

19) Cerroni L, Arzberger E, Putz B, et al : Primary cutaneous follicle center cell lymphoma with follicular growth pattern. Blood, 95 : 3922-3928, 2000

20) Rijlaarsdam JU, Toonstra J, Meijer OW, et al : Treatment of primary cutaneous B-cell lymphomas of follicle center cell origin : a clinical follow-up study of 55 patients treated with radiotherapy or polychemotherapy. J Clin Oncol, 14: 549-555, 1996

21) Sarris AH, Braunschweig I, Medeiros LJ, et al : Primary cutaneous non-Hodgkin's lymphoma of Ann Arbor stage I: preferential cutaneous relapses but high cure rate with doxorubicin-based therapy. J Clin Oncol, 19: 398-405, 2001

22) Bekkenk MW, Vermeer MH, Geerts ML, et al : Treatment of multifocal primary cutaneous B-cell lymphoma : a clinical follow-up study of 29 patients. J Clin Oncol, 17 : 2471-2478, 1999

23) Baba $Y$, Arakawa A, Furusawa M, et al : Radiation therapy of adult T-cell leukemia. Acta Oncol, 33 : 667-670, 1994 